\title{
AUTHENTIC FOOD SOUVENIR TO SUPPORT MSMES AND LOCAL WISDOM IN BANGKA BELITUNG, INDONESIA
}

\author{
Levyda LEVYDA* \\ Sahid University, Faculty of Economics and Business, Management Department, Jakarta, Indonesia, e-mail: levyda@usahid.ac.id
}

\author{
Kania RATNASARI
}

Sahid University, Faculty of Economics and Business, Management Department, Jakarta, Indonesia e-mail: kania.ratnasari@usahid.ac.id

\section{Giyatmi GIYATMI}

Sahid University, Faculty of Food Technology and Heath, Food Technology Department, Jakarta, Indonesia, e-mail: giyatmi@usahid.ac.id

\author{
Citation: Levyda, L., Ratnasari, K., \& Giyatmi, G. (2021). AUTHENTIC FOOD SOUVENIR TO SUPPORT MSMEs AND \\ LOCAL WISDOM IN BANGKA BELITUNG, INDONESIA. GeoJournal of Tourism and Geosites, 35(2), 531-536. \\ https://doi.org/10.30892/gtg.35234-681
}

\begin{abstract}
Authentic food souvenirs are essential in tourism, MSMEs and local wisdom. However, there is no satisfactory authentic assessment method yet, because it only examines objective or subjective aspects. Therefore, a more comprehensive study is needed; this study aims to assess authentic food souvenirs' authenticity with a geographic approach. Several stakeholders involved. It uses various methods of obtaining information. The result of this research is the superior authenticity of food souvenirs. Authentic food is useful for promoting destinations and increasing tourist spending. This assessment method can be an alternative in the assessment of authentic food souvenirs.
\end{abstract}

Key words: authentic food souvenirs, geographical approach, MSMEs, local wisdom

$* \quad * \quad * \quad * \quad * \quad *$

\section{INTRODUCTION}

Food souvenirs are very essential and are often bought by tourists (Kusdibyo, 2016).Tourists often buy food souvenirs to evoke memories and feel different experiences (Medeiros et al., 2017b) and motivate them to revisit it (Suhartanto et al., 2018). Food souvenirs can be used to promote cultural destinations (Huang et al., 2020) and have significant impact on the destination's economy (Huang et al., 2020). Hamzah et al. (2013) defined authentic food as "the originality and genuine of Malay cuisine in various aspects," and measured by family culture, self-interest, and awareness characteristics. Food souvenirs are specialty food that tourists buy in destinations and physically and mentally reflect the destination's identity (Sosianika et al., 2018). The forms of food souvenirs, according to (Buczkowska, 2014), are food and beverage products consumed after returning home, eating or cooking utensils, cooking recipe books, and photos of dishes sold in traditional markets, restaurants, or production sites. In Indonesia, food souvenirs are sold in gift shops and restaurants in meals, snacks, semi-finished food, and food raw materials. Authenticity is the most important characteristic in food souvenir (Altintzoglou et al., 2016) . Authentic food often interchanges with local food, traditional food and origin food, so this study discusses these four things. Authenticity can be seen in many ways. Based on the philosophical approach, there are three approaches to authenticity: objective, constructive or symbolic, and existential (Wang, 1999). In objective authenticity, there are authentic measurements that are objective or absolute. Constructive assumes that authenticity is a social construct related to views, beliefs, power, and social perspective. It is relative and negotiable, defined by contextual, and ideological. There are two dimensions in existential authenticity: interpersonal and intrapersonal authenticity. Intrapersonal authenticity involves physical experiences and feelings of tourists, while interpersonal authenticity, or social authenticity, is linked to traditions and community's emotions.

Normatively, the territoriality, communality, typicity and traditionality factors determine the originality of the food (Meulen, 2007). Territoriality describes the proximity of the distances between actors in the food supply chain. Communality explains how high the sharing experience is among actors. Typicity explains the uniqueness of ingredients and food production processes, while traditionality describes historical content reflected in legends, written documents, and rituals related to food.

Bowen and Zapata (2009) emphasized the importance of geographical identifications (GIs) to increase local bargaining actors to maintain control over production and prevent globalization's negative impacts. GIs is a place-based name that conveys geographic origin and cultural and historical identity, of agricultural products. Geographical Identification is a tool for framing products based on the product's geographic, cultural, historical and geographic origins. GIs is possible. Based on these opinions, authentic food souvenirs are produced by MSMEs and maintain local wisdom. According to the European Commission in Guerrero et al. (2009), traditional is proven to have been used by the user community for a minimum period of 25 years, and there is evidence that they are passed from one generation to the next. In the food context, traditional food uses conventional raw materials, and the composition of ingredients is arranged, processed, or produced traditionally. Guerrero et 
al. (2009) concluded that the dimensions of traditional food are foods often eaten, part of daily life, and often used (habit and natural), processed with simple technology (processing and elaboration) and rich in taste (tasteful), produced and marketed around the place of production, and contained local values in the area of production or marketing (origin and locality). Sidali and Hemmerling (2014) assess the authenticity of food based on subjective and objective assessments. Objective authenticity is an assessment based on objective things, such as the production process, the origin of materials, and production location.

In contrast, subjective authenticity is a subjective assessment of tourists, such as tourists' beliefs about the authenticity of products and product support for biodiversity diversity. Both subjective and objective measurements are needed to help understand perceived authentic food, Sidali and Hemmerling (2014) suggests using these two measurements. Objective assessment is less meaningful when not attracted tourists. Making food and consuming food determines the authenticity of food; therefore, authentic food is from the merchant, producer, and consumer and marketing officer's point of view (Lunchaprasith and Macleod, 2018). The merchant views authentic food as the process of creating old fashion food. Marketers view authenticity as the process of creating a traditional image, whereas visitors view authentic food based on their childhood experiences and unusual traditions. Criteria for food origin are different from perceived authentic food origin. Bryła (2015) found that the ten most important characteristics of origin food are traditionality, territoriality, high quality, healthiness, typicity, etc. Consumer knowledge determines the perceived authentic food origin. Bryla's survey results included several factors, such as natural taste, quality, place of sale and others Zhang et al. (2019) considers the experience of eating local food to be a cultural phenomenon so that he defines and measures authentic food with a constructive approach. Eating authentic food is a social construct that describes the imagination, expectations, preferences, beliefs, and capabilities of the product.

An authentic food experience is a combination of chefs, restaurants, recipes, and cuisines that evoke an atmosphere of local culture. The dimensions of authentic food souvenirs are cultural symbols, uniqueness of recipes, cooking methods, and various rituals in planting, processing, serving, and restaurant decorations. Authentic food souvenirs are original Bangka Belitung. The souvenir uses original raw materials from Bangka Belitung, processed based on local wisdom from generation to generation and sold in Bangka Belitung and consumed by residents, reflecting the norms, habits, and history of Bangka Belitung.

Food souvenirs are essential for tourism in Indonesia, particularly in Bangka Belitung Islands Province. The average expenditure of tourists for souvenir shopping is $4.6 \%$ of domestic tourist expenditure and $6.26 \%$ of foreign tourist expenditure (BPS - Statistics Indonesia, 2017). Food souvenirs are important for Bangka Belitung and are mostly produced by micro, small and medium enterprises (MSMEs). Furthermore MSMEs in the food sector is the largest. There are 18,543 businesses in the food sector $(70.38 \%)$ and provide 48,407 (67.45\%) workers. The income of microbusinesses and small businesses in 2017 reached 3.1 trillion IDR (Indonesian Rupiah), and the contribution of such businesses was 58.38\% (BPS-Statistics of Provinsi Kepulauan Bangka Belitung, 2020). Authentic food souvenirs are also needed to maintain local wisdom. Global cuisine threatens local cuisine (Mak et al., 2012); it can interfere with local wisdom. Local wisdom is the viewing of people, and their understanding of nature and interacting with it (Aswita et al., 2018). Local wisdom is collective knowledge and understanding, which is learned from generation to generation about various fields, including food preparation. Local wisdom plays a role in maintaining the authenticity of customs and culture. Thus, authentic food souvenirs play a role in maintaining the authenticity of customs and culture. In Indonesia, competition between destinations is very tight. There are five national super-priority destinations in Indonesia, ten national priority destinations, and eighty-eight strategic national tourism destinations, offering each food souvenirs. Therefore, each destination must have an authentic food souvenir just like Bangka Belitung. Currently there is no Bangka Belitung food which has become a national food. Bangka Belitung needs to establish authentic food souvenirs. There are many food souvenirs, so there is a need to study authentic food souvenirs. This study aims to analyze authentic food souvenirs in Bangka Belitung. The study of authenticity in food souvenir is still limited. Sosianika et al. (2018); Huang et al. (2020); Suhartanto et al. (2018); Medeiros et al. (2017b); Altintzoglou et al., (2016) examine authentic food from a tourist perspective. Authentic food is complicated, so it needs a more comprehensive discussion. This study fills the gaps in authentic food with a more thorough discussion involving many stakeholders (Wijaya et al., 2017) and using a geographic approach (Bowen and Zapata, 2009). This study involve tourists, food producers, food seller, and others as sources (Lunchaprasith and Macleod, 2018).

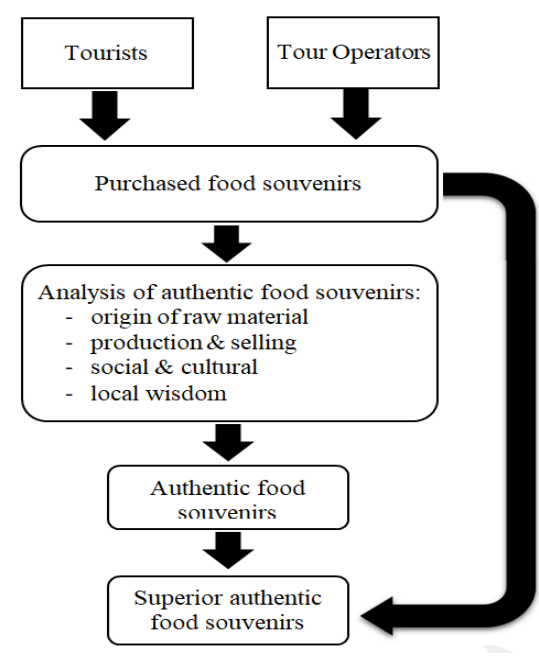

Figure 1. Research framework

\section{MATERIAL AND METHODS}

This research is qualitative. Interviews were conducted with tourists and souvenir producers and souvenir traders. A total of eighty-one tourists and were interviewed.

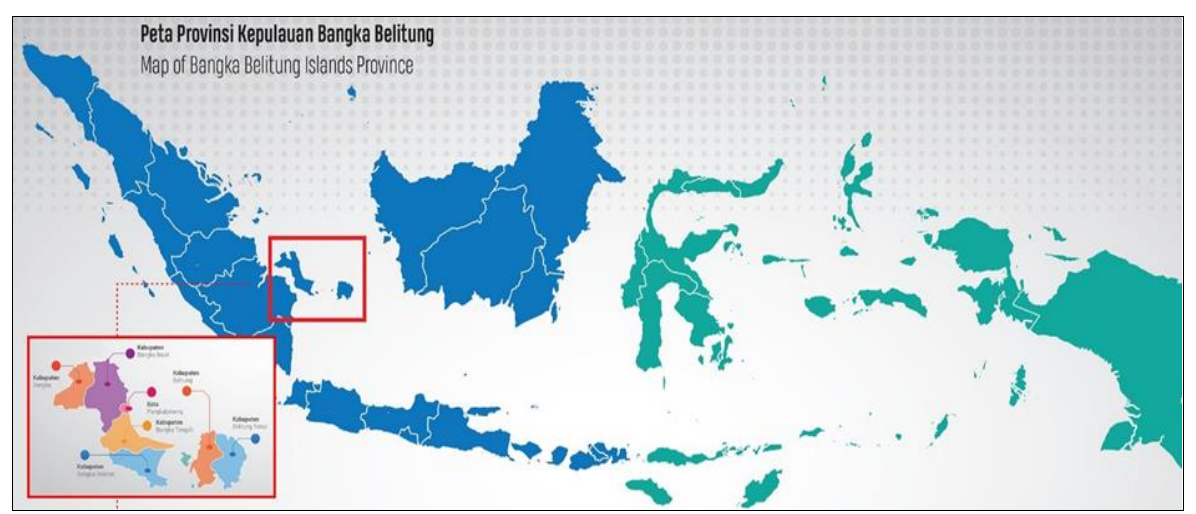

Figure 2. Bangka Belitung, Indonesia (Source: https://www.babelprov.go.id/content/aspek-geografis) 
The study uses an observation method in four food stores, eight restaurants, and four coffee shops in Pangkal Pinang and Tanjung Pandan in Belitung. This study also conducted in-depth interviews with thirteen tour operators. The purpose of the interview was to find out the food souvenirs that were purchased. The study will focus on purchased food souvenirs. Ten producers were interviewed. Interviews with producers aim to explore information on sources of raw materials, production processes, and marketing. Secondary data were used to assess the authenticity of the geographic, social, and local wisdom approaches. Local wisdom is also strengthened from the results of in-depth interviews with historian. Authentic food souvenirs are based on the results of the authenticity assessment, and products that are of interest to consumers are judged as superior products.

\section{RESULTS AND DISCUSSION}

In Bangka Belitung, food souvenirs can be grouped into ten: processed fish, dried poultry, salted and dried vegetables, processed coconut, flour and processed flour, sugar, confectionery, and honey, spices, spices, light drink, and powder drinks. Processed dry fish dominated the food souvenir. Type of dry fish is shredded fish (in Indonesia, it is called abon), dried squid, dried sea cucumber (teripang); some kind of fish crackers as as kemplang, kericu, pilus seaweed, and some kind of cake fish as otak-otak and pempek, gonggung snail. These are described in Table 1. There were 81 respondents interviewed: $36 \%$ of them were men and $64 \%$ were women.

Table 1. Food souvenir classification (Source: Primary Data Processed)

\begin{tabular}{|c|c|c|}
\hline Food group & Types of food souvenirs & Food processing \\
\hline \multirow{10}{*}{ Processed fish } & Sambal lingkung (shredded fish) & Frying and pressing \\
\hline & Ikan kering (dried fish), Teripang kering (dried sea cucumber) & Drying \\
\hline & Kemplang (a kind of fish crackers) & Frying \\
\hline & Kericu (a kind of fish crackers) & Frying \\
\hline & Getas (a kind of fish crackers) & Frying \\
\hline & Otak-otak (a kind of cake from a fish dough) & Steaming and roasting \\
\hline & Pempek (a kind of cake from a fish dough) & Steaming \\
\hline & Ikan asin (Salting fish) & Salting and drying \\
\hline & Terasi (shrimp paste) & Fermented \\
\hline & Siput gunggung (gunggung snails) & Frying \\
\hline Processed poultry & Sarang wallet (Swallow nest) & Cleaning and packing \\
\hline Dry vegetables & Jamur kulat (kullat mushroom) & Drying \\
\hline Processed flour & Assorted chips & Frying \\
\hline \multirow{2}{*}{ Processed fruit } & Dodol cempedak, dodol durian & Caramelization \\
\hline & Sukun chip, banana chip & Frying \\
\hline \multirow{3}{*}{$\begin{array}{l}\text { Confectionery, sweets, and } \\
\text { honey }\end{array}$} & Brown confectionery & Caramelization \\
\hline & Sweet kelubi fruit & Fermented \\
\hline & Honey & Filtering \\
\hline \multirow{2}{*}{ Seasonings } & Soy sauce & Fermentation \\
\hline & Lempah spice & Milling \\
\hline Herbs and spices & White and black pepper & Drying \\
\hline \multirow{3}{*}{$\begin{array}{l}\text { Soft drinks and powder } \\
\text { drinks }\end{array}$} & Sirop jeruk kunci & Extortion \\
\hline & Tea & Drying \\
\hline & Coffee powder & roasting, milling \\
\hline Processed grains or tubers & Sweet potato chips, sweet potato chips, green bean chips & Frying \\
\hline
\end{tabular}

Of these, $8.6 \%$ aged less than 20 years; $29.6 \%, \quad 20-30$ years old; $11 \%, 31-40$ years old; $9.16 \%, \quad 41-50$ years old; $16 \%, 51-60$ years old, and $7.01 \%$, over 60 years old. The purposes of visiting were as follows: visiting family, $12.34 \%$; conferences, $17.28 \%$; and offices and tours, $24.4 \%$. $49.6 \%$ of respondents have only visited Bangka Belitung once, $18.08 \%$ twice, and $25.92 \%$ thrice. The Respondents were asked to state the types of food souvenirs purchased. The types of products are described in Figure 2.

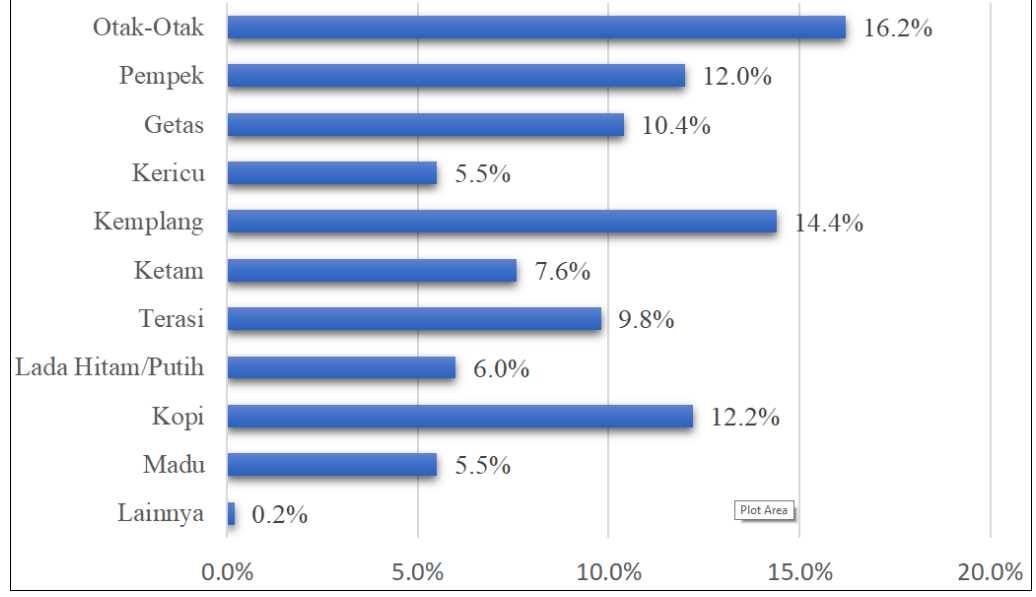

Figure 3. The Food Souvenirs Purchased by Tourists (Sources: Primary Data Processed) Thirteen tour operators were interviewed in this study. They convey the types of souvenirs tourists buy, such as otak-otak (28\%), pempek $(9,5 \%)$, ketam $(9,5 \%)$, kempalang $(23 \%)$, coffee $(95 \%)$ and others. Information from tour operators supports the interview results of respondents. Processed fish has the most types of souvenirs compared to other types. Processed fish products consist of shredded fish (abon ikan), dried squid, dried hisit, crackers, kemplang, aplang, squid chips (kericu), getas, shrimp paste, crab, empek-empek, otak-otak, rusip, gunggung snail, fish belly, seaweed pilus, fish skin, and salted fish. The processed dry poultry produced by Bangka Belitung is wallet bird's nest. The total area of the Bangka Belitung Islands Province reaches $81,725.06 \mathrm{~km}^{2} .79 .90 \%$ is the sea, and the rest is land. The sea produced many fish catches. The volume of fishing production in 2018 is $228,524.71$ tons worth IDR $8,361,881,814.15$, and the production volume of cultivated fish is 9,340.93 tons with a value of IDR 623,232,195.95 (Directorate General of Strengthening Competitiveness of Marine and Fisheries Products, Ministry of Marine Affairs and Fisheries, 2018). There are 73 types of fish caught in this area, including small pelagic, large pelagic, and demersal fish, consisting of 38 families (Kurniawan et al., 2019). The number of fish catches and fish cultivation is high, causing per capita fish consumption in Bangka 
Belitung to be high than other provinces in Indonesia. The fish catches are processed into various foods. It is reflected in the Bangka people's slogan, "Lom maken kalo dak lauk ikan", which means we have not eaten because we do not eat sea fish. Considering the importance of fish for the population, even though prices increase due to reduced supply, Bangka Belitung residents still buy sea fish. Per capita consumption of fish is highest than other food groups and exceeds national average consumption. The conclusions are supported by Levyda et al. (2019) and (Wulansari, 2016). The food eaten is influenced by social norms (Higgs and Thomas, 2016). Food, following social norms, is often consumed. A food survey conducted on Bangka Belitung resident shows that pempek and kemplang are the most frequently consumed, followed by otak-otak, kericu, rusip, chili sauce, and rintak biscuit. rusip, dodol cempedak, and gunggung snails are less often consumed (Levyda et al., 2019).

Processed fish has become local wisdom for the people of Bangka Belitung. These foods are in the poetry of the Bangka Malay community. Pantun, a kind of poem, is a literary that uses specific words and signs and symbols. It is a cultural heritage that contains advice, humor, puzzles, and even dimensions that are well packaged to be used in formal and informal situations (Wulansari, 2016). In the Pantun mention that the island of Bangka is surrounded by a sea rich in fish for daily consumption or for business. Pantun must pay attention to five things: the physical aspect, the value it contains, its function and uses, the extent of its use, and the sociocultural context (Tuti Andriani, 2012). The existence of these foods in the Bangka Malay poetry shows that these foods are following the sociocultural context for a long time ago. This shows that food souvenirs have been made some time ago based on local wisdom. Otak-otak, empek-empek, and various crackers made from seafood as daily food for the Bangka people since several centuries ago, their traces can be observed in Gedong Village, Bangka Regency (Setiati, 2010). They are made from fish or shrimp and then crushed with eggs and then stirred and mixed with sago flour. The dough is shaped oval and then steamed. The dough can be made soft or made into crackers. The process of making it is making dough, formed manually (Syaputra and Prasetiyono, 2017). According to Setiati (2010), typical Bangka foods such as, kemplang, keletek, empek-empek, otak-otak, lakso, and pantiaw were originally made by immigrants from China several centuries ago, which now belong to the Bangka community. Chinese people have been around for a long time and are related to the tin mining business. The Chinese have known Bangka Belitung since 1436, which is listed in classical Chinese books. The arrival of many Chinese occurred in 1710 as coolies on tin mining contracts by mining companies owned by Dutch people. Most of the Chinese people who came are Hakka from Guang Dong province. These traces can be observed in Gedong Village, Bangka Regency (Setiati, 2010). Until now, these foods have been produced in various places in Bangka Belitung and are consumed by the public. Balacan (shrimp paste) is widely known in Indonesia as a seasoning. It is made from small shrimp, anchovies, or other fish, which are fermented (Karim et al., 2014; Andriyani et al., 2012). It is produced in several places in Bangka Belitung and is traditionally made and uses recipes that have been learned and produced from generation to generation. Balacan or shrimp paste is made through the stages of salting, pressing, drying, milling, fermentation, crushing, and drying, among others (Andriyani et al., 2012) . Shrimp paste is a food that is often consumed and easily available (Levyda et al., 2019). Thus, the shrimp paste is an authentic food souvenir. Rusip is a meal of Bangka. It is the result of fermentation of anchovy, salt, and palm sugar (Yuliana, 2007) that is stored for 2 weeks and used as a chili mixture or for side dishes (Koesoemawardani, 2007). Fermentation techniques have been studied for generations, as obtained in Bangka Belitung (Levyda et al., 2019). Crab is one of the superior waters of Bangka Belitung, especially in Belitung. Crab production is 45 million tons per year. To increase the added value of crab, food MSMEs process crab into crabs. Processed foods for crab meat are easy to find in Belitung and are an everyday snack, so it is classified as authentic.

Based on the results of the interviews, eight entrepreneurs of food made from fish; four representing micro-entrepreneurs and four small-scale entrepreneurs. They use fish raw materials purchased from the market close to where they live. Microentrepreneurs use the production process is still done manually (handmade), and small companies use a semi-manual process. They are made from fish or shrimp and then crushed with eggs and then stirred and mixed with sago flour. The dough is shaped oval and then steamed. The dough can be made soft or made into crackers. The dough is manually formed. In microbusinesses, the volume of production is not continuous. They have received assistance from various government agencies and state-owned companies, while small businesses have been doing business for more than 25 years and are producing continuously. Micro-merchants and small entrepreneurs distribute products through conventional and online retail and through exhibitions. The differentiation they do is in the recipe, raw material, form of cracker, trademark, packaging, and sales method. The type of fish used can be determined by the color of the crackers, the taste, and the price of the product.

Coffee production in Bangka Belitung is relatively low. In 2018, only 7.77 tons/year came from Central Bangka and East Belitung. Although coffee production is relatively low, drinking coffee has been a culture for Bangka Belitung people for a long time. Several coffee shops have been around for a long time, such as the Tung Tau coffee shop in Bangka and the Ake, Kong Dji, and Atet coffee shop in Belitung. Warung Tung Tau was founded in 1938; the Ake coffee shop has been operating since 1922, the Atet coffee shop since 1949 (Erman, 2014), while the Kong Dji coffee shop since 1943. The Tung Tau coffee shop in Bangka was founded in 1938. The existence of a coffee shop is related to tin mining in Bangka Belitung since the eighteenth century. These coffee shops serve mining workers. Billiton Maatschappij in 1852 and Bangka Tin Winning in (Erman, 2014), companies owned by Dutch citizens, mostly used Chinese labor. The coffee shop provides coffee to be used as souvenirs. Based on the interviews with the coffee shop, they still use those from Lampung and Palembang due to limited local coffee products. In addition to coffee produced and sold by coffee shops, several Bangka Belitung MSMEs also produce coffee. Since it has been operating for more than 25 years (Guerrero et al., 2009), their coffee is an authentic product. Apart from coffee produced and sold by coffee shops, coffee is also produced by several Bangka Belitung MSMEs. The availability of abundant coffee and pepper raw materials encourages the creativity of MSMEs to produce pepper coffee.

Bangka Belitung is known as the biggest pepper producer in Indonesia. Pepper production in 2018 was 32,811 tons. Pepper is also one of the favorite souvenirs of tourists. The number of pepper management households is 111,757 (BPS-Statistics of Provinsi Kepulauan Bangka Belitung, 2020). For souvenirs, pepper is dried and packaged in plastic bottles of various sizes 
with various brands. In another form, pepper has been ground and packaged in plastic bottles and sold in souvenir shops. The cultivation of Bangka Belitung pepper has been encouraged since the Dutch colonial era in the nineteenth century (Budi et al., 2016) .Therefore, pepper souvenirs are categorized as authentic souvenirs. Bangka Belitung's non-timber forest products are honey, 1083.16 liters; mushrooms, 0.18 tons; and gaharu, 0.01 tons (BPS - Statistics Indonesia, 2016). Honey and mushrooms come from the Central Bangka Necklace Forest. The significant tree in the forest is the Pelawan tree. In the rainy season, the Pelawan tree grows a fungus called a Pelawan fungus. The nectar of the Pelawan tree flowers is sucked by honey bees, producing bitter honey (Akbarini, 2016). Pelawan honey and mushrooms are offered as authentic Bangka Belitung souvenirs sold in gift shops. Based on the data collected for the assessment of the authenticity of souvenirs, it is summarized as follows:

Table 2. Assessment of Authenticity Based

on Geography Approach (Sources: Primary Data Processed)

\begin{tabular}{|c|c|c|c|c|c|}
\hline $\begin{array}{c}\text { Food } \\
\text { Souvenir }\end{array}$ & $\begin{array}{c}\text { Raw } \\
\text { material }\end{array}$ & Production & Selling & $\begin{array}{c}\text { Social and } \\
\text { culture }\end{array}$ & $\begin{array}{c}\text { Local } \\
\text { Wisdom }\end{array}$ \\
\hline Otak-otak & Support & Support & Support & Support & Support \\
\hline Pempek & Support & Support & Support & Support & Support \\
\hline Kempalang & Support & Support & Support & Support & Support \\
\hline Getas & Support & Support & Support & Support & Support \\
\hline Kericu & Support & Support & Support & Support & Support \\
\hline Ketam & Support & Support & Support & Support & Support \\
\hline Rusip & Support & Support & Support & Support & Support \\
\hline Terasi & Support & Support & Support & Support & Support \\
\hline Kopi & Sot support & Support & Support & Support & Support \\
\hline Lada & Support & Support & Support & Support & Support \\
\hline Madu & Support & Support & Support & Support & Support \\
\hline
\end{tabular}

Table 3. Consumer Assessment and Authenticity

Conclusion (Source: Primary Data Processed)

\begin{tabular}{|c|c|c|}
\hline $\begin{array}{c}\text { Food } \\
\text { souvenir }\end{array}$ & $\begin{array}{c}\text { Consumer } \\
\text { purchases }\end{array}$ & $\begin{array}{c}\text { Authenticity } \\
\text { Conclusion }\end{array}$ \\
\hline Otak-otak & Very high & Very high \\
\hline Pempek & Very high & Very high \\
\hline Kempalang & Very high & Very high \\
\hline Getas & High & Very high \\
\hline Kericu & Low & Very high \\
\hline Ketam & High & Very high \\
\hline Rusip & Very low & Very high \\
\hline Terasi & High & Very high \\
\hline Kopi & High & High \\
\hline Lada & Low & Very high \\
\hline Madu & Low & Very high \\
\hline
\end{tabular}

Not all authentic souvenirs are in demand by tourists, so a destination needs to choose authentic food and is in order by tourists for various purposes, such as promoting culinary tourism. Based on consumer surveys and authentic food, Bangka Belitung can use otak-otak, pempek, and kemplang for promotion. Essential factors in shopping for souvenirs are tangibility, brand and packaging, value, and food quality. Tangibility is the most important factor, including environmentally friendly, attractive packaging, and producer image. Food quality is also an essential factor, so food souvenirs must meet standards, taste good, and use natural raw materials. The aspects of value are the usefulness of food souvenirs and economical in price.

The brand and packaging of food souvenirs must have a unique brand and an attractive package design (Sosianika et al., 2018). Authentic souvenirs must be attractive and economical, must meet the standards, and must have an attractive brand name so that consumers will remember. Tourists buy food souvenirs with packaging suitable with transportation and hygienic and sanitary conditions and if there is the name of the place visited and where the product is traditionally produced (Medeiros et al., 2017a). Food souvenirs show the identity of the area of origin of the food and drink, are packaged according to product characteristics, easy to carry by tourists, can remember the origin of the souvenirs visited by tourists and even motivate tourists to come again to the area origin of souvenirs (Horodyski et al., 2014). Producers of souvenirs need to be innovative while still maintaining the authenticity of the product, since culinary tourism is part of the urban lifestyle, eating to get new experiences. Eating is an expression of human freedom, and culinary tourism supports the expression of human freedom. Traditional food needs to follow the egoistic changes of its audience. Food life cycle is getting shorter (Setiawan, 2019).

\section{CONCLUSION}

The assessment method for authentic food souvenirs produces an assessment that reflects Bangka Belitung's geography and reflects tourists' interest. Tourist assessment is critical because food authenticity is nothing if the tourist does not interestconsumers' involvement in a geographic approach, resulting in authentic food that attracts tourists. The limitations of primary and secondary data are a weakness in the assessment. With the development of online sales, tourists can buy food souvenirs without having to visit a destination. For future research, new definitions and methods of assessment may be needed.

\section{Acknowledgement}

This research was funded by Ministry of Research and Technology of the Republic of Indonesia. The researchers did not have any interstitial conflict with this study.

\section{REFERENCES}

Akbarini, D. (2016). Pohon Pelawan (Tristaniopsis merguensis): Spesies Kunci Berkelanjutan Taman Keanekaragaman Hayati NamangBangka Tengah [Pelawan Tree (Tristaniopsis merguensis): Species Key Sustainability in Namang Biodiversity Park-Central Namang]. Al-Kauniyah Jurnal Biologi, 9(1), 66-73. https://doi.org/10.15408/kauniyah.v9i1.3500

Altintzoglou, T., Heide, M., \& Borch, T. (2016). Food souvenirs: buying behaviour of tourists in Norway. British Food Journal, 118(1), 119-131. https://doi.org/http://dx.doi.org/10.1108/BFJ-05-2015-0190

Andriyani, E., Yuliati, K., \& Supriadi, A. (2012). Efisiensi Dan Identifikasi Loss Pada Proses Pengolahan Terasi Udang Rebon (Acetes sp) Di Desa Belo Laut Kecamatan Muntok Bangka Belitung [Efficiency and Identification of Loss in The Processing Process of Shrimp Paste (Acetes sp)In Belo Laut Village, Munt. Fishtech, 1(1), 26-40. https://doi.org/https://doi.org/10.36706/fishtech.v1i1.795

Aswita, D., Suryadarma, I.G.P., \& Suyanto, S. (2018). Local wisdom of sabang island society (aceh, Indonesia) in building ecological intelligence to support sustainable tourism. Geojournal of Tourism and Geosites, 22(2), 393-402. https://doi.org/10.30892/gtg.22210-297

Bowen, S., \& Zapata, A.V. (2009). Geographical indications, terroir, and socioeconomic and ecological sustainability: The case of tequila. Journal of Rural Studies, 25(1), 108-119. https://doi.org/10.1016/j.jrurstud.2008.07.003

Bryła, P. (2015). The role of appeals to tradition in origin food marketing. A survey among Polish consumers. Appetite, 91, 302-310. https://doi.org/10.1016/j.appet.2015.04.056 
Buczkowska, K. (2014). Local Food and Beverage Products As Important Tourist Souvenirs. Turystyka Kulturowa, 2014(1), 47-58.

Budi, A., Suhaidar, Wahyudin, N., \& Pranoto, Y. (2016). Kajian Model Pembiayaan Komoditas Lada Di Provinsi Kepulauan Bangka Belitung [Study of Pepper Cultivation Financing Model in Bangka Belitung Islands Province]. In Kantor Perwakilan Bank Indonesia Provinsi Kepulauan Bangka Belitung, 7( 9).

Erman, E. (2014). Dinamika Komunitas Warung Kopi Dan Politik Resistensi Di Pulau Belitung [Dynamics of Coffee Shop Community and Political Resistance in Belitung Island]. Masyarakat Indonesia, 40(1), 89. https://doi.org/10.14203/jmi.v40i1.108

Guerrero, L., Guàrdia, M.D., Xicola, J., Verbeke, W., Vanhonacker, F., Zakowska-Biemans, S., Sajdakowska, M., Sulmont-Rossé, C., Issanchou, S., Contel, M., Scalvedi, M.L., Granli, B.S., \& Hersleth, M. (2009). Consumer-driven definition of traditional food products and innovation in traditional foods. A qualitative cross-cultural study. Appetite, 52(2), 345-354. https://doi.org/10.1016/j.appet.2008.11.008

Hamzah, H., Ab Karim, M.S., Othman, M., \& Hamzah, A. (2013). Dimensions of Authenticity in Malay Cuisine from Experts' Perspectives. Academic Journal of Interdisciplinary Studies, 2(3), 369-378. https://doi.org/10.5901/ajis.2013.v2n3p369

Higgs, S., \& Thomas, J. (2016). Social influences on eating. Current Opinion in Behavioral Sciences, 9, 1-6. https://doi.org/10.1016/ j.cobeha.2015.10.005

Horodyski, G., Manosso, F.C., Bizinelli, C., \& Gândara, J.M. (2014). Gastronomic Souvenirs as Travel Souvenirs: A Case Study in Curitiba, Brazil. Via Tourism Review, 6, 0-20. https://doi.org/10.4000/viatourism.732

Huang, S.C.L., Wang, C.Y., \& Yan, Y.R. (2020). Motivational typology of online food souvenir shoppers and their travel-related intentions. Sustainability (Switzerland), 12(18). https://doi.org/10.3390/su12187624

Karim, F., Swastawati, F., \& Anggo, A. (2014). Pengaruh Perbedaan Bahan Baku Terhadap Kandungan Asam Glutamat Pada Terasi [The Effect of Different Raw Material to Glutamic Acid Content in Fish Paste]. Jurnal Pengolahan Dan Bioteknologi Hasil Perikanan, 3(4), 51-58. https://ejournal3.undip.ac.id/index.php/jpbhp/article/view/7778/7533

Koesoemawardani, D. (2007). Analisis Sensori Rusip Dari Sungailiat-Bangka [Sensory Analysis of Rusip From Sungai liat-Bangka]. Jurnal Teknologi Dan Industri Hasil Pertanian, 12(2), 36-39.

Kurniawan, Asmarita, \& Supratman, O. (2019). Identifikasi Jenis Ikan (Penamaan Lokal, Nasional Dan Ilmiah) Hasil Tangkapan Utama (Htu) Nelayan Dan Klasifikasi Alat Penangkap Ikan Di Pulau Bangka Provinsi Kepulauan Bangka Belitung [Identification of Fish Types (Local, National and Scientific Name) Re. Akuatik: Jurnal Sumberdaya Perairan, 13(1), 42-51. https://doi.org/10.33019/akuatik.v13i1.1107

Kusdibyo, L. (2016). Examining Souvenir Shopping Tourists' Behaviour Across Cultures. 317-321. https://doi.org/10.2991/atf-16.2016.47

Levyda, L., Giyatmi, G., \& Ratnasari, K. (2019). What is the authentic food in this destination? The 2nd Mulawarman International Conference on Economics and Business, 25-30. http://journal.feb.unmul.ac.id/index.php/MICEBProceeding/article/view/7059/900

Lunchaprasith, T., \& Macleod, D. (2018). Food tourism and the use of authenticity in Thailand. Tourism, Culture and Communication, 18(2), 101-116. https://doi.org/10.3727/109830418X15230353469492

Mak, A.H.N., Lumbers, M., \& Eves, A. (2012). Globalisation and food consumption in tourism. Annals of Tourism Research, 39(1), 171196. http://www.sciencedirect.com.proxy.lib.ul.ie/science/article/pii/S0160738311000946

Medeiros, M. de L., Horodyski, G.S., \& Passador, J.L. (2017a). Food souvenirs in the perception of the tourist: the case of the artisanal minas Serro cheese. Brazilian Journal of Tourism Research, 11(2), 347-364.

Medeiros, M. de L., Horodyski, G.S., \& Passador, J.L. (2017b). Food souvenirs in the perception of the tourist: the case of the artisanal minas Serro cheese TT - Gastronomic souvenirs from the tourists perspectives: the case of the artisanal minas serro cheese TT - Souvenirs gastronômicos na percepção do turista: o. Revista Brasileira de Pesquisa Em Turismo, 11(2), 347-364. https://doi.org/10.7784/rbtur.v11i2.1307

Meulen, Van der H. (2007). A normative definition method for origin food products -Anthropology of food. Social Science Information, 18(6), 895-897. https://doi.org/10.1177/053901847901800604

Setiati, D. (2010). Budaya Masyarakat Cina di Desa Gedong Kabupaten Bangka [Chinese Culture in the Village of Kampung Gedong Bangka Regency]. In Kementerian Kebudayaan dan Pariwisata Balai Pelestarian Sejarah clan Nilai Tradisional Tanjungpinang 2010. https://doi.org/10.1017/CBO9781107415324.004

Setiawan, R. (2019). Memaknai Kuliner Tradisional diNusantara: Sebuah Tinjauan Etis [Interpreting Traditional Culinary in the Archipelago: An Ethical Overview]. Etika Respons, 21(01), 113-140.

Sidali, K.L., \& Hemmerling, S. (2014). Developing an authenticity model of traditional food specialties : Does the self-concept of consumers matter? British Food Journal, 116(11), 1692-1709. https://doi.org/http://dx.doi.org/10.1108/BFJ-02-2014-0089

Sosianika, A., Suhaeni, T., Wibisono, N., \& Suhartanto, D. (2018). The Dimension of Food Souvenir: An Exploratory-Confirmatory Factor Analysis. MATEC Web of Conferences, 218, 1-6. https://doi.org/10.1051/matecconf/201821804002

Suhartanto, D., Dean, D., Sosianika, A., \& Suhaeni, T. (2018). Food souvenirs and their influence on tourist satisfaction and behavioural intentions. European Journal of Tourism Research, 18, 133-145.

Syaputra, D., \& Prasetiyono, E. (2017). Analisis Proksimat, Kadar Timbal dan Kadar Formalin Total Keripik Telur Cumi (Keritcu) [Proxymate Analysis, Lead and Total Formaldehyde Contents of Squid Eggs Crackers]. 7, 181-190.

Tuti Andriani (2012). Pantun Dalam Kehidupan Melayu (Pendekatan Historis Dan Antropologis) [Pantun in Malay Life (Historical and Anthropological Approach)]. Jurnal Sosial Budaya, 9(2), 195-211.

Wang, N. (1999). Rethinking Authenticity in Tourism Experience. Annals of Tourism Research, 26(2), 349-370.http://citeseerx.ist.psu. edu/viewdoc/download?doi=10.1.1.470.7142\&rep=rep1\&type=pdf

Wijaya, S., King, B., Morrison, A., \& Nguyen, T.H. (2017). Destination encounters with local food: The experience of international visitors in Indonesia. Tourism, Culture and Communication, 17(2), 79-81. https://doi.org/10.3727/109830417X14966810027526

Wulansari, D. (2016). Bahasa Pantun Dalam Makna Dan Budaya Masyarakat Melayu Bangka: Sebuah Kajian Etnolingguistik [Pantun Language in the Meaning and Culture of Bangka Malay Sociaty: An Etnolinguistic Study]. Jurnal Society, VI(1), 1-14.

Yuliana, N. (2007). Profil Fermentasi "Rusip" Yang Dibuat Dari Ikan Teri (Stolephorus sp) [Fermentation Profile of Rusip Made from Anchovies]. Agritech: Jurnal Fakultas Teknologi Pertanian UGM, 27(1), 12-17. https://doi.org/10.22146/agritech.9488

Zhang, T., Chen, J., \& Hu, B. (2019). Authenticity, quality, and loyalty: Local food and sustainable tourism experience. Sustainability (Switzerland), 11(12), 1-18. https://doi.org/10.3390/su10023437

*** BPS-Statistics of Provinsi Kepulauan Bangka Belitung. (2020). Provinsi Bangka Belitung Dalam Angka 2020 [Kepulauan Bangka Belitung Province in Figure 2020]. BPS-Statistics of Provinsi Kepulauan Bangka Belitung. https://babel.bps.go.id/publication/ download.html?nrbvfeve=MjU0ZWU4MzBkZmI4MzUzNTFmMGEwYjk3\&xzmn=

*** BPS - Statistics Indonesia. (2016). Statistik Produksi Kehutanan [Statistics of Forestry Production ]. Badan Pusat Statistik/BPSStatistics Indonesia. https://www.bps.go.id/publication/download.html?nrbvfeve=YjI4ODE3Zjk5ZDEzOTE4NzFINTUxYWJk\&xzmn

*** BPS - Statistics Indonesia. (2017). Neraca Satelit Pariwisata Nasional (NASPERNAS) 2017 [National Tourism Satellite Account 2017] (Subdirectorate of Tourism Statistic (ed.)). Badan Pusat Statistik. https://www.bps.go.id/publication/2019/03/26/66604e9f077983c $15 \mathrm{~b} 80 \mathrm{e} 2 \mathrm{bc} /$ neraca-satelit-pariwisata-nasional--nesparnas--201 